Prosiding Penelitian \& Pengabdian Kepada Masyarakat e ISSN : 2581-

1126 p ISSN :

2442-448X
Vol 6, No: 2

Hal: $123-180$

\title{
PENGARUH KARAKTERISTIK PSIKOGRAFIS ANGGOTA PROGRAM RKO BINAAN CSR TBBM CIKAMPEK TERHADAP MOTIVASI MENGIKUTI PROGRAM DI DESA DAWUAN BARAT, KECAMATAN CIKAMPEK, KABUPATEN KARAWANG
}

\author{
Ardi Hutri Prayitno \\ 1, Taufik Ismail ${ }^{2}$, Reza Rinaldy $^{3}$, Sahadi Humaedi ${ }^{4}$ \\ 1,2,3PT. Pertamina Terminal BBM Cikampek; \\ ${ }^{4}$ Pusat Studi CSR, Kewirausaan Sosial dan Pengembangan Masyarakat Unpad
}

ardi.hutri@pertamina.com; idtaufikismail@gmail.com; rezarinaldy94@gmail.com;

Sahadi.humaedi@unpad.ac.id

\begin{abstract}
ABSTRAK
Program RKO merupakan implementasi kepedulian PT. Pertamina Terminal BBM Cikampek dalam merealisasikan program CSR yang mengacu pada potensi masyarakat. Berlokasikan di salah satu desa binaan yaitu Desa Dawuan Barat, penelitian ini melakukan pengambilan data dari lima dusun yang terdiri atas Dusun Payuyon, Tegalwangi, Babakan Bogor, Babakan Sereh, dan Kamijaya. Adapun penelitian ini bertujuan untuk mengukur tingkat anggota RKO dalam aktivitas program CSR Pertamina TBBM Cikampek dan menganalisis pengaruh karakteristik demografi peternak berupa umur, tingkat pendidikan dan pekerjaan utama, terhadap motivasi mengikuti program RKO. Sampel data penelitian adalah 15 responden anggota RKO yang aktif mengikuti program. Menggunakan metode Survei dibantu dengan kuesioner teknik convenience sampling, yang diperdalam melalui wawancara. Analisis data secara deskriptif dan kuantitatif menggunakan Regresi Linear Berganda. Dari hasil lapangan dan pengolahan data primer, dapat disimpulkan bahwa dari segi kebutuhan badaniyah dan kebutuhan keamanan mayoritas responden menyatakan tidak setuju dengan pernyataan yang diajukan sehingga motivasi responden tergolong sedang. Sedangkan dari segi kebutuhan sosial, kebutuhan penghargaan, dan kebutuhan kepuasan diri mayoritas responden menyatakan setuju dari pertanyaan yang diajukan sehingga motivasi responden tergolong sedang bahkan tinggi. Hal ini menunjukkan bahwa Program RKO belum mampu memenuhi kebutuhan responden secara ekonomi. Namun telah mampu meningkatkan kebutuhan responden secara sosial dan kemasyarakatan serta peningkatan motivasi responden dalam mengikuti program yang dilaksanakan.
\end{abstract}

Kata Kunci: Program RKO, Karateristik Psikografis, Motivasi. 


\section{PENDAHULUAN}

Kepedulian Perusahaan terhadap masyarakat sekitar lingkungan operasional perusahaan menjadi hal penting sebagai upaya membangun harmonisasi hubungan dan memberikan dampak positif bagi masyarakat baik dalam segi ekonomi, sosial, dan lingkungan. Implementasi kepedulian direalisasikan dalam program-program Corporate Social Responsibility (CSR). Pelaksanaan program CSR dilaksanakan dengan mengacu kepada potensi masyarakat. Singkronisasi potensi masyarakat dengan program yanang akan dilaksanakan harus sesuai sehingga capaian bersama yang diharapkan baik oleh masyarakat maupun perusahaan dapat tercapai. Salah satu program CSR PT Pertamina (Persero) Terminal BBM Cikampek adalah Program Rumah Kelola Organik. Program ini diimplementasikan di salah satu desa binaan CSR PT Pertamina (Persero) Terminal BBM Cikampek yaitu Desa Dawuan Barat.

Rumah Kelola Organik Dawuan Barat memiliki 2 sub program yaitu Program Budidaya Tanaman Hydroponik dan Pengolahan Tanaman. Kedua sub program merupakan program terpadu yang bertujuan untuk melestarikan lingkungan melalui budidaya tanaman dan peningkatan ekonomi melalui pengolahan tanaman hydrponik karena tanaman hydroponik dapat memiliki nilai ekonomi yang tinggi bila dikelola dengan baik. Implementasi program Rumah Kelola Ogranik Ini tidak akan berjalan dengan baik tanpa adanya keterlibatan masyarakat Desa Dawuan Barat. Faktor psikografi dan motivasi anggota program menjadi faktor pendukung yang kuat dalam proses pelaksanaan program Rumah Kelola Organik.

Program Rumah Kelola Organik memiliki berbagai macam sub program atau biasa disebut kegiatan turunan. Kegiatan turunan dari Rumah Kelola Organik adalah pengolahan tanaman herbal yang berintegrasi dengan program TOGA Posyandu Sehati dan Pengolahan tanaman hydroponik berintegrasi dengan Posyandu Sehati untuk peningkatan gizi ibu dan bayi.
Adapun penelitian ini bertujuan untuk mengukur tingkat anggota RKO dalam aktivitas program CSR Pertamina TBBM Cikampek serta menganalisis pengaruh karakteristik demografi peternak berupa umur, tingkat pendidikan dan pekerjaan utama, terhadap motivasi mengikuti program RKO.

\section{METODE}

Penelitian ini dilaksanakan di Desa Dawuan Barat, Kecamatan Cikampek Kabupaten Karawang. Materi yang digunakan dalam penelitian ini adalah anggota kelompok RKO (Rumah Kelola Organik) Binaan CSR Petamina Cikampek sebanyak 15 responden yang tersebar di 5 dusun yaitu dusun Tegalwangi, Babakan Bogor, Payuyon, Kamijaya, Babakan Sereh dengan menggunakan alat bantu dalam pengambilan data adalah kuesioner. Metode yang digunakan adalah metode survei yang meliputi 4 tahap. Tahap pertama yaitu dengan melakukan survei lokasi untuk pendataan peternak dan mengetahui gambaran daerah penelitian. Tahap kedua yaitu membuat dan menguji kuesioner yang diuji validitas dan reabilitasnya. Tahap ketiga yaitu pengumpulan data dengan alat bantu kuesioner. Tahap keempat yaitu melakukan analisis terhadap data yang telah dikumpulkan.

\section{HASIL DAN PEMBAHASAN Data Psikografis Responden}

Tabel 1. Distribusi Umur Reponden

\begin{tabular}{ccc}
\hline $\begin{array}{c}\text { Umur } \\
\text { Responden } \\
\text { (tahun) }\end{array}$ & $\begin{array}{c}\text { Jumlah } \\
\text { Responden } \\
\text { (orang) }\end{array}$ & $\begin{array}{c}\text { Persentase } \\
(\%)\end{array}$ \\
\hline$<15$ & 0 & 0 \\
$15-64$ & 15 & 100,0 \\
$>64$ & 0 & 0
\end{tabular}

Rata-rata umur responden 44,5 thn

Sumber : Data primer terolah (2019)

Hasil yang didapat dari data primer yang telah terolah menunjukkan $100 \%$ umur responden tergolong pada umur produktif. Hal ini menunjukkan bahwa umur responden sudah mencukupi untuk dimintai keterangan. 
Tabel 2. Distribusi Tingkat Pendidikan Reponden

\begin{tabular}{lcc}
\hline \hline $\begin{array}{c}\text { Tingkat } \\
\text { Pendidikan }\end{array}$ & $\begin{array}{c}\text { Jumlah } \\
\text { Responde } \\
\text { n (orang) }\end{array}$ & $\begin{array}{c}\text { Persentase } \\
(\%)\end{array}$ \\
\hline Tidak Sekolah & 0 & 0 \\
SD (Tidak lulus) & 0 & 0 \\
SD (Lulus) & 3 & 20 \\
SMP (Lulus) & 8 & 54 \\
SMA (Lulus) & 4 & 26 \\
Mayoritas lulusan SMP & \\
Sumber : Data primer terolah (2019) \\
Hasil data primer diatas menunjukkan \\
bahwa mayoritas responden adalah \\
lulusan SMP, dengan presentase sebesar \\
54\%, disusul dengan lulusan SMA dan \\
SD sebesar 26\% dan 20\%
\end{tabular}

Tabel 3. Distribusi Pekerjaan Utama Responden

\begin{tabular}{lcc}
\hline \hline $\begin{array}{c}\text { Pekerjaan } \\
\text { Utama }\end{array}$ & $\begin{array}{c}\text { Jumlah } \\
\text { Responden } \\
\text { (orang) }\end{array}$ & $\begin{array}{c}\text { Persentase } \\
(\%)\end{array}$ \\
\hline Ibu Rumah & 15 & 100 \\
Tangga & 0 & 0 \\
Selain IRT & 0
\end{tabular}

Sumber : Data primer terolah (2019)

Hasil data primer menunjukkan 100\% responden bekerja sebagai ibu rumah tangga.

\section{Motivasi Mengikuti Program Kebutuhan Badaniyah}

Tabel 4. Distribusi persentase (\%) jawaban responden terhadap setiap pernyataan kebutuhan badaniyah $(n=15)$

\begin{tabular}{ccccccc}
\hline \hline $\mathrm{N}$ & \multicolumn{1}{c}{ Pernyataan } & $\mathrm{S}$ & & & $\mathrm{ST}$ \\
$\mathrm{O}$ & $\mathrm{S}$ & $\mathrm{S}$ & $\mathrm{R}$ & $\mathrm{TS}$ & $\mathrm{S}$ \\
\hline 1. & $\begin{array}{l}\text { Saya mengikuti } \\
\text { program agar dapat } \\
\text { menambah } \\
\text { penghasilan utk } \\
\text { kebutuhan makan } \\
\text { dan minum sehari- } \\
\text { hari untuk seluruh } \\
\text { anggota keluarga. }\end{array}$ & & & & & \\
Dengan mengikuti \\
program, saya dapat \\
membangun dan atau \\
memperbaiki rumah.
\end{tabular}

3. Dengan mengikuti program RKO, saya $\begin{array}{llllll}\text { dapat mencukupi } 0 & 5 & 20 & 75 & 0\end{array}$ kebutuhan untuk membeli pakaian.

4. Dengan mengikuti program RKO, saya

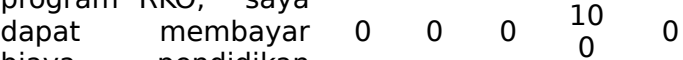
biaya pendidikan anak.

5. Dengan mengikuti program RKO saya $\begin{array}{llllll}\text { dapat terhindar dari } & 0 & 0 & 10 & 80 & 10\end{array}$ kemiskinan

Sumber: Data primer terolah (2019)

Dari ke-5 point diatas, mayoritas responden menyatakan tidak setuju terhadap pertanyaan yang diajukan terkait pemenuhan kebutuhan badaniyah program RKO. Hal ini dapat dilihat dari point pertama sampai point kelima, dimana pernyataan tidak setuju selalu berada pada angka tertinggi, yang diikuti dengan pernyataan ragu-ragu dari responden.

Tabel 5. Distribusi Motivasi Kategori Komponen Kebutuhan Badaniyah

\begin{tabular}{cccc}
\hline \hline Kategori & Skor & $\begin{array}{c}\text { Jumlah } \\
\text { (orang } \\
\text { ) }\end{array}$ & $\begin{array}{c}\text { Persentas } \\
\text { e (\%) }\end{array}$ \\
\hline Rendah & $5,0-11,6$ & 2 & 14 \\
Sedang & $11,7-18,3$ & 12 & 80 \\
Tinggi & $18,4-25,0$ & 1 & 7 \\
\hline
\end{tabular}

Sumber: Data primer terolah (2019)

Hasil data primer yang telah diolah menunjukkan bahwa mayoritas responden memiliki motivasi dengan kategori sedang dengan skor 11-7,18,3 dan persentase $80 \%$.

\section{Kebutuhan Keamanan}

Tabel 6. Distribusi persentase (\%) jawaban responden terhadap setiap pernyataan kebutuhan keamanan $(n=15)$

\begin{tabular}{cllllll}
\hline \hline No & \multicolumn{1}{c}{ Pernyataan } & SS & S & R & TS & STS \\
\hline 1. & $\begin{array}{l}\text { Mengikuti program } \\
\text { RKO tidak berisiko } \\
\text { tinggi di masyarakat }\end{array}$ & 20 & 80 & 0 & 0 & 0 \\
2. & $\begin{array}{l}\text { Pendapatan dari } \\
\text { mengikuti RKO dapat } \\
\text { dipergunakan } \\
\text { sebagai tabungan. }\end{array}$ & 0 & 5 & 10 & 70 & 15 \\
\hline & Sumber: Data primer terolah (2019) &
\end{tabular}


Dari data primer diatas, $80 \%$ responden setuju bahwa program RKO tidak menimbulkan

resiko tinggi dalam kehidupan bermasyarakat. Dan $70 \%$ dari responden menyatakan tidak setuju pendapatan mengikuti RKO dapat mereka pergunakan sebagai tabungan.

Tabel 7. Distribusi motivasi kategori komponen

kebutuhan keamanan

\begin{tabular}{cccc}
\hline \hline Kategori & Skor & $\begin{array}{c}\text { Jumlah } \\
\text { (orang) }\end{array}$ & $\begin{array}{c}\text { Persentas } \\
\text { e (\%) }\end{array}$ \\
\hline Rendah & $5,0-6,6$ & 0 & 0 \\
Sedang & $6,7-8,3$ & 11 & 74 \\
Tinggi & $8,4-10,0$ & 4 & 26 \\
\hline
\end{tabular}

Sumber: Data primer terolah (2019)

Dari olahan jawaban responden terhadap kebutuhan keamanan, motivasi responden tergolong sedang dengan skor 6,7-8,3 dengan persentase sebesar $74 \%$.

\section{Kebutuhan Sosial}

Tabel 8. Distribusi persentase (\%) jawaban responden terhadap setiap pernyataan kebutuhan sosial $(n=15)$

\begin{tabular}{|c|c|c|c|c|c|c|}
\hline No & Pernyataan & SS & S & $\mathrm{R}$ & TS & STS \\
\hline 1. & $\begin{array}{lr}\text { Sebagai } & \text { anggota } \\
\text { RKO, saya } & \text { merasa } \\
\text { diterima } & \text { dan } \\
\text { dihormati } & \text { dalam } \\
\text { pergaulan } & \text { dengan } \\
\text { lingkungan sekitar. }\end{array}$ & 30 & 65 & 5 & 0 & 0 \\
\hline 2. & $\begin{array}{l}\text { Sebagai anggota } \\
\text { RKO, saya sering } \\
\text { berpartisipasi dalam } \\
\text { kegiatan kelompok } \\
\text { dan masyarakat } \\
\text { sekitar. }\end{array}$ & 60 & 30 & 10 & 0 & 0 \\
\hline
\end{tabular}

Sumber: Data primer terolah (2019)

Kebalikan dari pemenuhan kebutuhan badaniyah, mayoritas responden menyatakan setuju bahkan sangat setuju bahwa program RKO dapat meningkatkan kebutuhan sosial mereka. Dimulai dari program RKO yang membuat mayoritas responden merasa diterima dan dihormati pergaulan lingkungan sekitar sampai pada peningkatan partisipasi mereka dalam kegiatan kemasyarakatan.
Tabel 9. Distribusi motivasi kategori komponen

kebutuhan sosial

\begin{tabular}{lccc}
\hline \hline $\begin{array}{l}\text { Kategor } \\
\mathrm{i}\end{array}$ & Skor & $\begin{array}{c}\text { Jumla } \\
\mathrm{h} \\
\text { (oran } \\
\mathrm{g})\end{array}$ & $\begin{array}{c}\text { Persenta } \\
\text { se (\%) }\end{array}$ \\
\hline Rendah & $5,0-6,6$ & 0 & 0 \\
Sedang & $6,7-8,3$ & 6 & 40 \\
Tinggi & $8,4-$ & 9 & 60 \\
\hline Sumber: Data primer terolah (2019)
\end{tabular}

Untuk komponen kebutuhan sosial, data primer olahan menunjukkan bahwa untuk motivasi responden tergolong tinggi dengan skor 8,4-10,0 dan presentase sebesar $60 \%$

\section{Kebutuhan Penghargaan}

Tabel 10. Distribusi persentase (\%) jawaban responden terhadap setiap pernyataan kebutuhan penghargaan $(n=15)$

\begin{tabular}{|c|c|c|c|c|c|c|}
\hline $\begin{array}{l}N \\
0\end{array}$ & Pernyataan & SS & $\mathrm{S}$ & $\mathrm{R}$ & TS & STS \\
\hline 1. & $\begin{array}{lr}\text { Saya } & \text { merasa } \\
\text { dihargai } & \text { oleh } \\
\text { masyarakat } & \text { sebagai } \\
\text { anggota } & \text { kelompok } \\
\text { RKO. }\end{array}$ & 25 & 60 & $\begin{array}{l}1 \\
0\end{array}$ & 5 & 0,0 \\
\hline 2. & $\begin{array}{l}\text { Agar menjadi contoh } \\
\text { bagi anggota } \\
\text { keluarga, saya giat } \\
\text { mengikuti program } \\
\text { RKO. }\end{array}$ & 40 & 60 & 0 & 0 & 0,0 \\
\hline 3. & $\begin{array}{l}\text { Saya turut } \\
\text { berpartisipasi dalam } \\
\text { kegiatan program } \\
\text { RKO agar diterima } \\
\text { dan dihargai oleh } \\
\text { sesama anggota. }\end{array}$ & 35 & 55 & 5 & $\begin{array}{l}5, \\
0\end{array}$ & 0,0 \\
\hline 4. & $\begin{array}{l}\text { Pujian dari sesama } \\
\text { anggota } \\
\text { membuat saya lebih } \\
\text { bersemangat. }\end{array}$ & 40 & 55 & 5 & 0 & 0,0 \\
\hline 5. & $\begin{array}{lr}\text { Jika saya } & \text { terus aktif } \\
\text { dalam } & \text { kelompok } \\
\text { saya } & \text { akan } \\
\text { mendapat } & \text { pujian } \\
\text { dari teman-teman } \\
\text { sesama } & \text { anggota } \\
\text { kelompok } & \text { dan } \\
\text { masyarakat lainnya }\end{array}$ & 25 & 60 & $\begin{array}{l}1 \\
0\end{array}$ & $\begin{array}{l}5, \\
0\end{array}$ & 0,0 \\
\hline
\end{tabular}

Dari data primer yang telah diolah menunjukkan bahwa mayoritas 
responden setuju dengan pernyataan program RKO dapat memenuhi kebutuhan penghargaan mereka. Hal ini dapat dilihat dari mayoritas responden yang menyatakan merasa lebih diterima dan dihargai baik oleh keluarga maupun masyarakat, membuat mereka lebih aktif dan semangat karena pujian dari sesama anggota RKO, serta giat mengikuti program untuk menjadi contoh dalam keluarga.

Tabel 11. Distribusi motivasi kategori komponen kebutuhan penghargaan

\begin{tabular}{cccc}
\hline \hline Kategori & Skor & $\begin{array}{c}\text { Jumlah } \\
\text { (orang) }\end{array}$ & $\begin{array}{c}\text { Persentase } \\
(\%)\end{array}$ \\
\hline Rendah & $5,0-11,6$ & 0 & 0,0 \\
Sedang & $11,7-18,3$ & 10 & 67 \\
Tinggi & $18,4-25,0$ & 5 & 33 \\
\hline
\end{tabular}

Sumber: Data primer terolah (2019)

Dari data primer ditas menunjukkan motivasi responden terkait komponen kebutuhan penghargaan tergolong sedang dengan skor 11,7-18,3 dan persentase sebesar $67 \%$.

\section{Kebutuhan Kepuasan Diri}

Tabel 12. Distribusi persentase (\%) jawaban responden terhadap setiap pernyataan kebutuhan kepuasan diri $(n=15)$

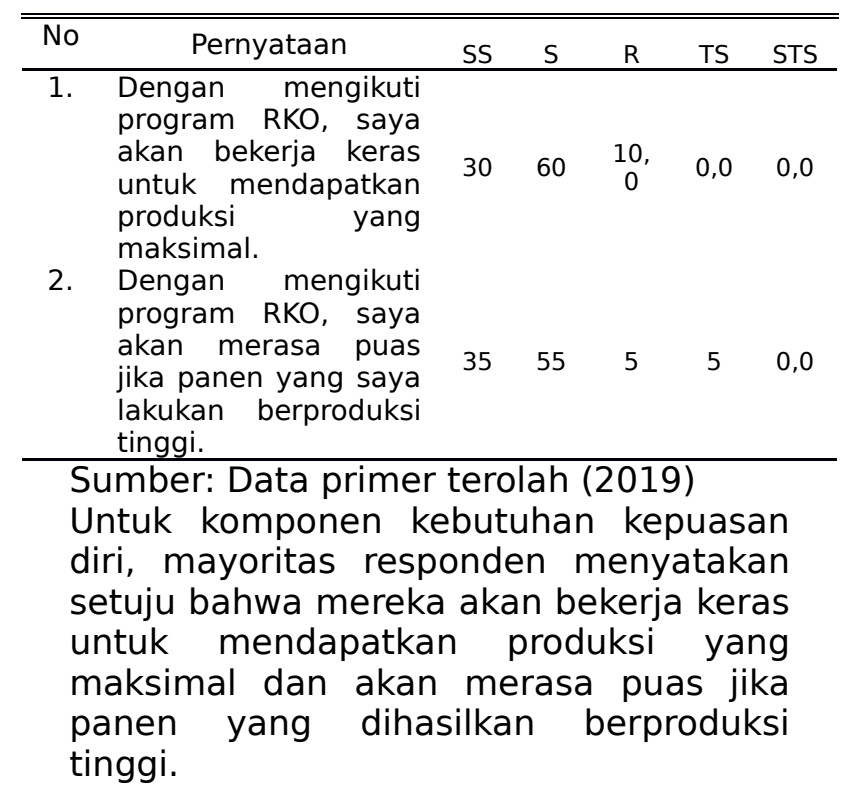

Tabel 13. Distribusi motivasi kategori komponen kebutuhan kepuasan diri

\begin{tabular}{cccc}
\hline \hline $\begin{array}{c}\text { Kategor } \\
\mathrm{i}\end{array}$ & Skor & $\begin{array}{c}\text { Jumlah } \\
\text { (orang } \\
\text { ) }\end{array}$ & $\begin{array}{c}\text { Persenta } \\
\text { se }(\%)\end{array}$ \\
\hline Rendah & $5,0-6,6$ & 0 & 0 \\
Sedang & $6,7-8,3$ & 7 & 47 \\
Tinggi & $8,4-$ & 8 & 53 \\
\hline Sumber: Data primer terolah (2019)
\end{tabular}

Motivasi responden terkait komponen kebutuhan kepuasan diri tergolong tinggi, dengan skor $8,4-10,0$ dan persentase sebesar $53 \%$

\section{TINGKAT MOTIVASI MENGIKUTI PROGRAM RKO}

Tabel 14. Distribusi tingkat motivasi

\begin{tabular}{cccc}
\hline Kategori & Skor & $\begin{array}{c}\text { Jumla } \\
\mathrm{h} \\
\text { (orang } \\
\text { ) }\end{array}$ & $\begin{array}{c}\text { Persentase } \\
(\%)\end{array}$ \\
\hline Rendah & $16,0-37,3$ & 1 & 7 \\
Sedang & $37,4-58,7$ & 10 & 67 \\
Tinggi & $58,8-80,0$ & 4 & 27 \\
\hline
\end{tabular}

Sumber: Data primer terolah (2019)

Dari data primer yang telah diolah diatas, menunjukkan mayoritas motivasi responden berada pada posisi sedang dengan skor 37,4-58,7 dengan persentase sebesar $67 \%$.

\section{Analisis Pengaruh Karakteristik Psikografi Terhadap Motivasi Mengikuti Program RKO}

Pengujian pengaruh karakteristik psikografis terhadap motivasi digunakan analisis regresi linear berganda dimana yang menjadi variabel bebas (independent) adalah umur $\left(X_{1}\right)$, pendidikan $\left(X_{2}\right)$, pekerjaan utama $\left(X_{3}\right)$, Pendidikan Terakhir $\left(X_{4}\right)$, sedangkan yang menjadi variabel terikat/tidak bebas (dependent) adalah motivasi (Y). 


\begin{tabular}{|c|c|c|c|c|}
\hline $\begin{array}{c}\text { Prosiding Penelitian \& } \\
\begin{array}{c}\text { Pengabdian Kepada } \\
\text { Masyarakat }\end{array}\end{array}$ & $\begin{array}{c}\text { e ISSN : 2581- } \\
\text { I126 p ISSN : } \\
2442-448 X\end{array}$ & Vol 6, No: 2 & Hal: $123-180$ & Juli 2019 \\
\hline
\end{tabular}

Tabel 15. Hasil output analisis regresi linier berganda

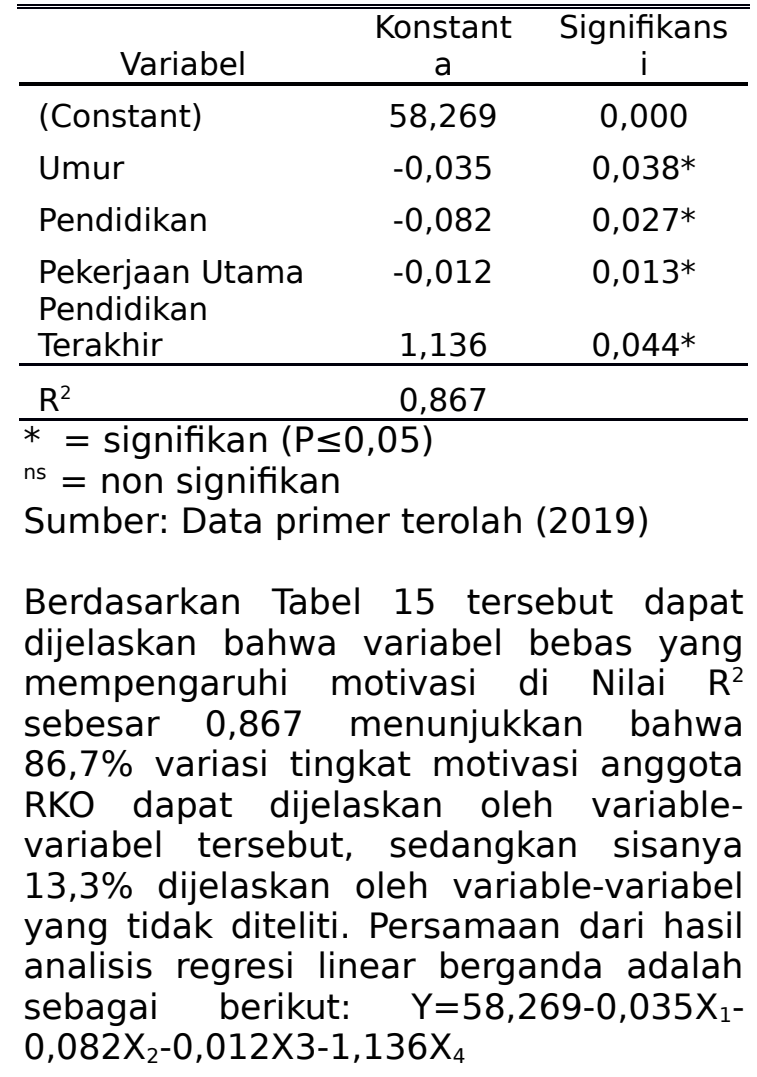

\section{PENUTUP}

\section{Simpulan}

Dari hasil lapangan dan pengolahan data primer, dapat disimpulkan bahwa dari segi kebutuhan badaniyah dan kebutuhan keamanan mayoritas responden menyatakan tidak setuju dengan pernyataan yang diajukan sehingga motivasi responden tergolong sedang. Sedangkan dari segi kebutuhan sosial, kebutuhan penghargaan, dan kebutuhan kepuasan diri mayoritas responden menyatakan setuju dari pertanyaan yang diajukan sehingga motivasi responden tergolong sedang bahkan tinggi. Hal ini menunjukkan bahwa Program RKO belum mampu memenuhi kebutuhan responden secara ekonomi. Namun telah mampu meningkatkan kebutuhan responden secara sosial dan kemasyarakatan.

\section{Saran}

1) Perlu adanya strategi program yang diarahkan kepada peningkatan income kelompok sasaran. Hal ini bisa dilakukan dengan melakukan beberapa inovasi terkait produktifitas tanam organic serta mengadakan sosialisasi manfaat dari penanaman organic untuk meningkatkan motivasi kelompok sasaran.

2) Perlu adanya kegiatan yang dapat melibatkan stake holder khususnya dari pihak konsumen yang dapat memanfaatkan produk RKO tersebut

\section{Daftar Pustaka}

Indrajit, Wisnu dan Soimin. 2014. Pemberdayaan Masyarakat dan Pembangunan. Jakarta: Intrans Publishing.

Maslow, Abraham. 2006. Mazhab Ketiga: Psikologi Humanistik. Edisi ke 11. Diterjemahkan oleh: Drs. A. Supratinya. Surabaya: Kanisius.

Rasyad, Rashidan. 2003. Metode Deskriptif untuk Umum. Jakarta: Gramedia Widiasarana. Indonesia.

Santoso, Singgih. 2010. Statistik Parametrik: Konsep dan Aplikasi dengan SPSS. Jakarta: PT. Elex Media Komputindo

Unaradjan, Dominikus Dolet. 2019. Metode Penelitian Kuantitatif. Jakarta: Universitas Katolik Indonesia Atmajaya.

Wibhawa, Budi. 2017. Model Pemberdayaan Masyarakat Perspektif Pekerjaan Sosial. Jatinangor: Unpad Press.

Yusuf, Muri. 2017. Metode Penelitian Kuantitatif, Kualitatif, dan Penelitian Gabungan. Jakarta: Kencana. 


\begin{tabular}{|c|c|c|c|c|}
\hline Prosiding Penelitian \& & e ISSN : 2581- & Vol 6, No: 2 & Hal: $123-180$ & Juli 2019 \\
$\begin{array}{c}\text { Pengabdian Kepada } \\
\text { Masyarakat }\end{array}$ & $\begin{array}{c}1126 \text { p ISSN : } \\
2442-448 X\end{array}$ & & & \\
\hline
\end{tabular}


